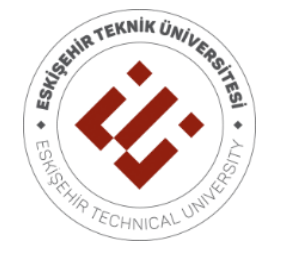

\title{
INVESTIGATION OF THERMAL AND STRUCTURAL PROPERTIES OF NITRIC, HYDROCHLORIC AND SULPHURIC ACID-TREATED ZEOLITE
}

\author{
Çağatay EZBER ${ }^{1}$, Meryem AKBELEN,"* \\ ${ }^{1}$ Graduate School of Science, Eskişehir Technical University, Eskisehir, Turkey \\ 2,* Department of Physics, Faculty of Science, Eskişehir Technical University, Eskisehir, Turkey
}

\begin{abstract}
In this study, in order to consider the effect of the hydrochloric acid $(\mathrm{HCl})$, nitric acid $\left(\mathrm{HNO}_{3}\right)$ and sulphuric acid $\left(\mathrm{H}_{2} \mathrm{SO}_{4}\right)$ treatments on thermal and structural properties, zeolite was modified with $1 \mathrm{M}$ acid solutions at $70{ }^{\circ} \mathrm{C}$ during $4 \mathrm{~h}$ using batch method. The structural and thermal properties of zeolites were studied by X-ray diffraction (XRD), X-ray fluorescence (XRF), thermogravimetric analysis (TG), differential thermogravimetric analysis (DTG) and differential thermal analysis (DTA). Quantitative XRD analysis show that the natural zeolite mainly consists of mordenite and clinoptilolite with varying amounts of quartz, feldspar and clay mineral. TG-DTG and DTA curves of all zeolite samples were obtained in the temperature range between 30 and $1000^{\circ} \mathrm{C}$. Based on the TG results, the total mass losses for all acid-treated samples (8.51-8.44 \%) are less than that of the natural $(\mathrm{Z})$ sample $(10.14 \%) . \mathrm{SiO}_{2} / \mathrm{Al}_{2} \mathrm{O}_{3}$ ratio of the natural zeolite sample $(\mathrm{Z})$ increased from 5.6 to 9.8, 9.7 and 8.8 in the Z-N, Z-H and Z-S samples, respectively, indicating the removal of the significant amount of aluminum from the zeolite structure.
\end{abstract}

Keywords: Natural zeolite, Clinoptilolite, Mordenite, XRD, XRF, TG-DTG-DTA

\section{INTRODUCTION}

Zeolites are hydrated aluminosilicates with three-dimensional framework constructed from $\mathrm{SiO}_{4}$ or $\mathrm{AlO}_{4}$ tetrahedra joined by sharing common oxygen atoms. The net negative charge due to the substitution of $\mathrm{Si}^{4+}$ by $\mathrm{Al}^{3+}$ in tetrahedral positions is balanced by the exchangeable $\mathrm{K}^{+}, \mathrm{Na}^{+}$and $\mathrm{Ca}^{2+}$ cations within these pores. Clinoptilolite $\left(\left(\mathrm{K}_{2}, \mathrm{Na}_{2}, \mathrm{Ca}\right)_{3}\left[\mathrm{Al}_{6} \mathrm{Si}_{30} \mathrm{O}_{72}\right]\right)$ a member of the heulandite group (HEU) of zeolites and its structure is characterized by three different types of pore channels with sizes of $(7.2 \AA \mathrm{x}$ $4.4 \AA),(4.0 \AA$ x $5.5 \AA)$ and $(4.1 \AA \times 4.0 \AA)$, respectively $[1,2] .10$-membered channel (A) and 8-memmered channel (B) are parallel to each other and to the c-axis. The other 8-membered channel (C) running along the a-axis intersecting both $\mathrm{A}$ and $\mathrm{B}$ channels [3]. Mordenite $\left(\mathrm{Na}_{8} \mathrm{Al}_{8} \mathrm{Si}_{40} \mathrm{O}_{96} \cdot \mathrm{nH}_{2} \mathrm{O}\right)$ is one of the high silica natural zeolites. It has a one-dimensional ellipsoidal 12-ring channels $(6.5 \AA \times 7.0 \AA)$ with side pockets involving 8-ring channels $(2.6 \AA \times 5.7 \AA)[4,5]$. The characteristics of natural zeolites can be changed by acid activation $\left(\mathrm{HCl}, \mathrm{HNO}_{3}\right.$ and $\mathrm{H}_{2} \mathrm{SO}_{4}$ ) [6-20]. Partial dealumination of the zeolites lead to improve in the thermal stability and increase in the hydrophobicity.

Abundant deposits of zeolitic tuffs have been discovered in many countries. Volcano-sedimentary zeolite occurrences are common in Turkey. The Heulandite-Clinoptilolite group of zeolite deposits is major occurrences, especially in Gördes and Bigadic. In addition, the natural zeolite reserve in Turkey is estimated to be about 50 billion tons [21]. The aim of this study is to investigate the effect of acidtreatment on structural and thermal properties of the natural zeolite sample $(Z)$ and its acid-treated forms (Z-N, Z-S and Z-H) using XRD, XRF and TG-DTG-DTA analysis.

*Corresponding Author: msakizci@eskisehir.edu.tr

Received: 11.10.2019 Published: 16.12.2019 


\section{MATERIALS AND METHODS}

\subsection{Materials and chemicals}

Zeolite sample from Sivas-Yavu region of Turkey was ground to less than $45 \mu \mathrm{m}$. Acid treated forms of zeolite were prepared with $1 \mathrm{M} \mathrm{HCl}, 1 \mathrm{M} \mathrm{H}_{2} \mathrm{SO}_{2}$ and $1 \mathrm{M} \mathrm{HNO}_{3}$ acid solutions in a shaker for 4 hours at $70{ }^{\circ} \mathrm{C}$. After this process, solutions were filtered and the sample was washed several times with deionized water at boiling point and then dried at room temperature. Before the experimental processes, all samples were dried for 16 hours in a $110^{\circ} \mathrm{C}$ oven and then stored in a desiccator. The resulting acidactivated samples are referred to below as Z-H, Z-S and Z-N, respectively, denoting their $1 \mathrm{M} \mathrm{HCl}$, $1 \mathrm{M} \mathrm{H}_{2} \mathrm{SO}_{4}$ and $1 \mathrm{M} \mathrm{HNO}_{3}$ treatments. The organic chemicals like $\mathrm{HCl}, \mathrm{H}_{2} \mathrm{SO}_{4}$ and $\mathrm{HNO}_{3}$ were provided by Merck (Darmstadt, Germany), and all solutions were prepared using deionized water.

\subsection{Characterization}

Chemical compositions were determined on powdered samples fused with lithium tetraborate using Xray fluorescence analysis (XRF - Rigaku ZSX Primus instrument). The XRD diffractograms were obtained with a Rigaku, RINT-2200 model instrument, using $\mathrm{CuK} \alpha$ radiation $(\lambda=1.54 \AA$ ), $40 \mathrm{kV}$ and 30 $\mathrm{mA}$ power supply over the scan range of $2 \theta=3$ to $70^{\circ}$ with an incremental step size of $0.02^{\circ}$. The TGADTG-DTA experiments carried out with a Setsys Evolution Setaram analyzer using a rate of $10^{\circ} \mathrm{C} / \mathrm{min}$ from $30^{\circ} \mathrm{C}$ to $1000^{\circ} \mathrm{C}$. Approximately $30 \mathrm{mg}$ was used in each run.

\section{RESULTS AND DISCUSSION}

\subsection{Chemical Analysis}

The chemical composition of the zeolite samples in terms of $\%$ mass of oxides is determined in Table 1. As seen in Table 1, the major cations of natural zeolite were $\mathrm{Si}, \mathrm{Al}, \mathrm{Ca}, \mathrm{Fe}$ in addition to small amounts of $\mathrm{Na}, \mathrm{Mg}$ and $\mathrm{K}$. Ca in zeolites originated from feldspar and mordenite as well as clinoptilolite. A significant decrease in the $\mathrm{Na}, \mathrm{Ca}$ and $\mathrm{Mg}$ cations, along with $\mathrm{Al}$, was detected as a result of treatment the zeolite with $1 \mathrm{M} \mathrm{HCl}, 1 \mathrm{M} \mathrm{H}_{2} \mathrm{SO}_{4}$ and $1 \mathrm{M} \mathrm{HNO}_{3}$ acid solutions. $\mathrm{Na}$ cations were completely removed from the structure of the zeolite treated with $1 \mathrm{M} \mathrm{HNO}_{3}$ acid solution. It was also seen that $\mathrm{SiO}_{2}$ content, which is insoluble in acid solution, increased considerably after acid treatments (Table 1).

$\mathrm{SiO}_{2} / \mathrm{Al}_{2} \mathrm{O}_{3}$ ratio of $\mathrm{Z}$ sample increased from 5.6 to 9.8, 9.7 and 8.8 in the Z-N, Z-H and Z-S samples, respectively, indicating the removal of the significant amount of aluminum from the zeolite structure. Similar changes were obtained in the literature before $[7,9,12,22]$.

Table 1. Chemical analyses in oxides (\%) for natural and acid treated zeolite samples

\begin{tabular}{lcclc}
\hline $\begin{array}{l}\text { Chemical } \\
\text { analysis }(\%)\end{array}$ & $\mathrm{Z}$ & $\mathrm{Z}-\mathrm{H}$ & $\mathrm{Z}-\mathrm{N}$ & $\mathrm{Z}-\mathrm{S}$ \\
\hline $\mathrm{SiO}_{2}$ & 68.232 & 78.078 & 77.981 & 77.485 \\
$\mathrm{Al}_{2} \mathrm{O}_{3}$ & 12.126 & 8.026 & 7.899 & 8.746 \\
$\mathrm{CaO}$ & 4.872 & 1.336 & 1.354 & 1.432 \\
$\mathrm{Fe}_{2} \mathrm{O}_{3}$ & 2.194 & 1.659 & 1.771 & 1.706 \\
$\mathrm{MgO}$ & 0.767 & 0.356 & 0.332 & 0.346 \\
$\mathrm{~K}_{2} \mathrm{O}$ & 0.745 & 0.608 & 0.649 & 0.653 \\
$\mathrm{Na}_{2} \mathrm{O}$ & 0.709 & 0.281 & - & 0.305 \\
$\mathrm{TiO}_{2}$ & 0.293 & 0.323 & 0.401 & 0.390 \\
$\mathrm{P}_{2} \mathrm{O}_{5}$ & 0.080 & - & - & 0.014 \\
$\mathrm{SO}_{3}$ & 0.025 & 0.021 & -0.041 \\
$\mathrm{Others}^{\mathrm{LOI}}$ & 0.004 & 0.004 & 0.002 & 0.004 \\
$\mathrm{SiO}_{2} / \mathrm{Al}_{2} \mathrm{O}_{3}$ & 9.953 & 9.308 & 9.611 & 8.878 \\
\hline & 5.6 & 9.7 & 9.8 & 8.8 \\
\hline
\end{tabular}




\subsection{X-ray Analysis}

In order to investigate the influence of $1 \mathrm{M} \mathrm{HCl}, 1 \mathrm{M} \mathrm{H}_{2} \mathrm{SO}_{4}$ and $1 \mathrm{M} \mathrm{HNO}_{3}$ treatments on the crystal structure of zeolite, the XRD patterns of all the samples (Z, Z-N, Z-S and Z-H) are given in Figure 1. The XRD patterns of the samples indicate the presence of mordenite $(d=13.50,6.55,5.09,4.50$ and $d$ $=3.45 \AA)$ and clinoptilolite $(\mathrm{d}=8.97,7.85,4.63$ and $3.96 \AA)$ as the major zeolite phases $[8,23]$. In addition, it contains quartz $(\mathrm{d}=4.26$ and $3.33 \AA)$ and feldspar $(\mathrm{d}=3.18 \AA)$.

While a significant decrease in the intensities of clinoptilolite peaks at $d=8.97$ and $3.96 \AA$ is seen in the XRD pattern of acid-treated samples, it is observed that the intensities of the quartz peaks at $d=4.26$ and $3.33 \AA$ are highly increased $[6,7,11]$. This could be attributed to partial dealumination and the partial collapse of the zeolite structure (Figure 1). These results confirm the XRF data (Table 1). On the other hand, the intensity of the mordenite phase appeared to be hardly affected by acid treatment.

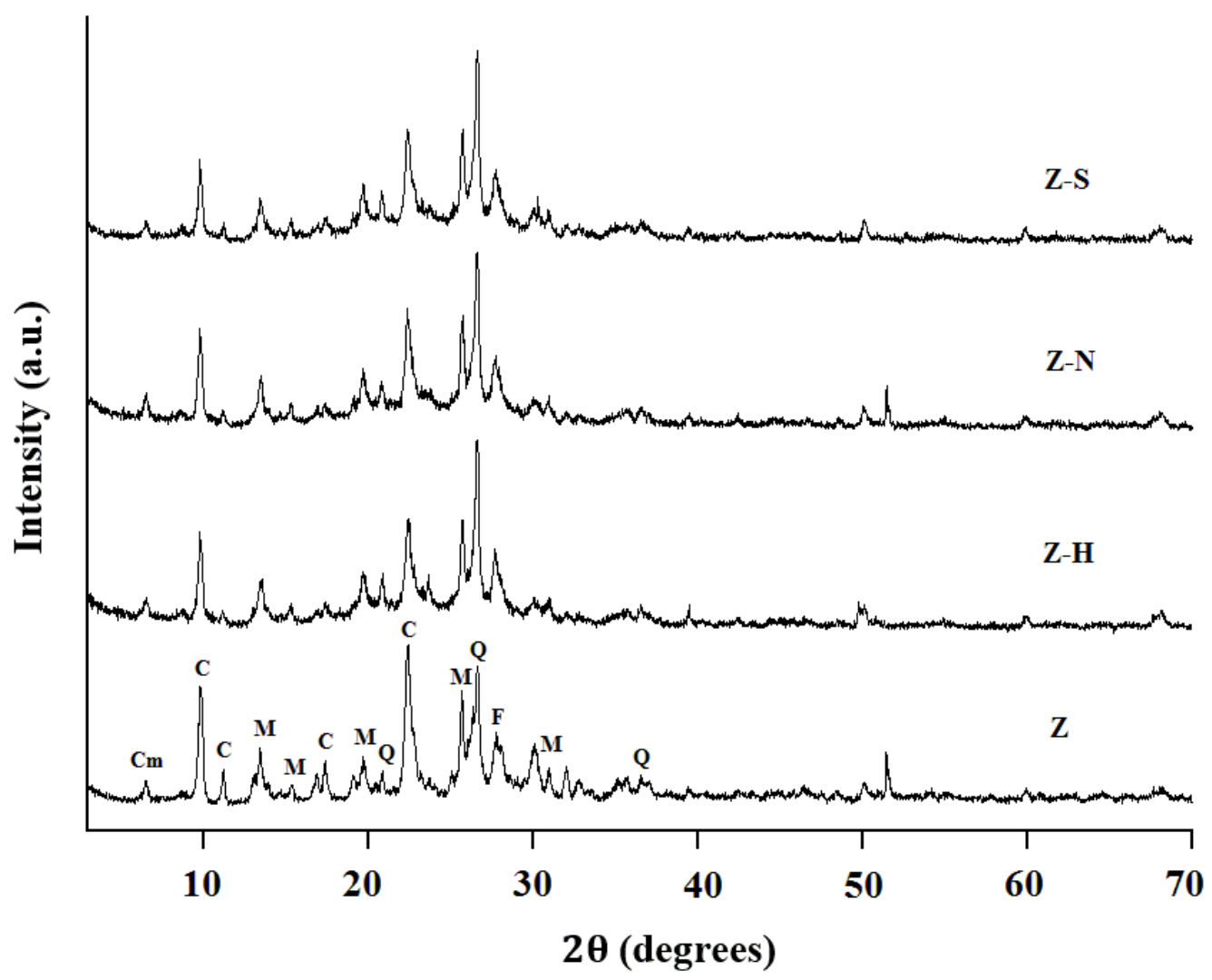

Figure 1. XRD patterns of natural and acid treated zeolite samples (M: mordenite; C: clinoptilolite; F: feldspar; Q: quartz; Cm: clay mineral)

\subsection{Thermal Analysis}

The TG-DTG-DTA curves of zeolite samples (Z, Z-N, Z-S and Z-H) are shown in Figure 2. The DTA curve of the natural zeolite $(Z)$ sample showed three endothermic peaks at $170{ }^{\circ} \mathrm{C}, 481{ }^{\circ} \mathrm{C}$ and $693{ }^{\circ} \mathrm{C}$. The DTA curves of the Z-H, Z-S and Z-N samples displayed on broad endothermic peak at temperature range between 153 and $158^{\circ} \mathrm{C}$ as a result of a single step dehydration process (Figure 2). Endothermic peak temperatures increased in the sequence Z-H $\left(153{ }^{\circ} \mathrm{C}\right) \rightarrow$ Z-N $\left(156{ }^{\circ} \mathrm{C}\right) \rightarrow$ Z-S $\left(158{ }^{\circ} \mathrm{C}\right)$. The decomposition temperatures of Z-H, Z-S and Z-N samples shifted to lower temperatures compared with natural zeolite. 
The temperature intervals and mass loss data obtained by TG-DTG analysis are given in Table 2 . TG analysis of all the zeolites exhibited that the mass loss was continuous during heating up to $700{ }^{\circ} \mathrm{C}$. In the temperature range from 30 to $200{ }^{\circ} \mathrm{C}$, the major and rapid mass loss $(2.90-2.73 \%)$ is due to the elimination of physisorbed water, the water residing in the zeolite cavities and loosely bonded water associated with extra-framework cations. This removal showed a high peak in the DTG curve (Figure 2). In the range between 200 and $500{ }^{\circ} \mathrm{C}$, more tightly bonded water is removed. At the higher temperatures, the isolated $\mathrm{OH}$ groups are lost. Based on the TG results, the total mass losses for all acidtreated samples (8.51-8.44\%) are less than that of the natural $(\mathrm{Z})$ sample (10.14\%). This can be assigned to the loss of exchangeable cations and dealumination due to the acid treatment with hydrochloric, sulphuric and nitric acid solutions.
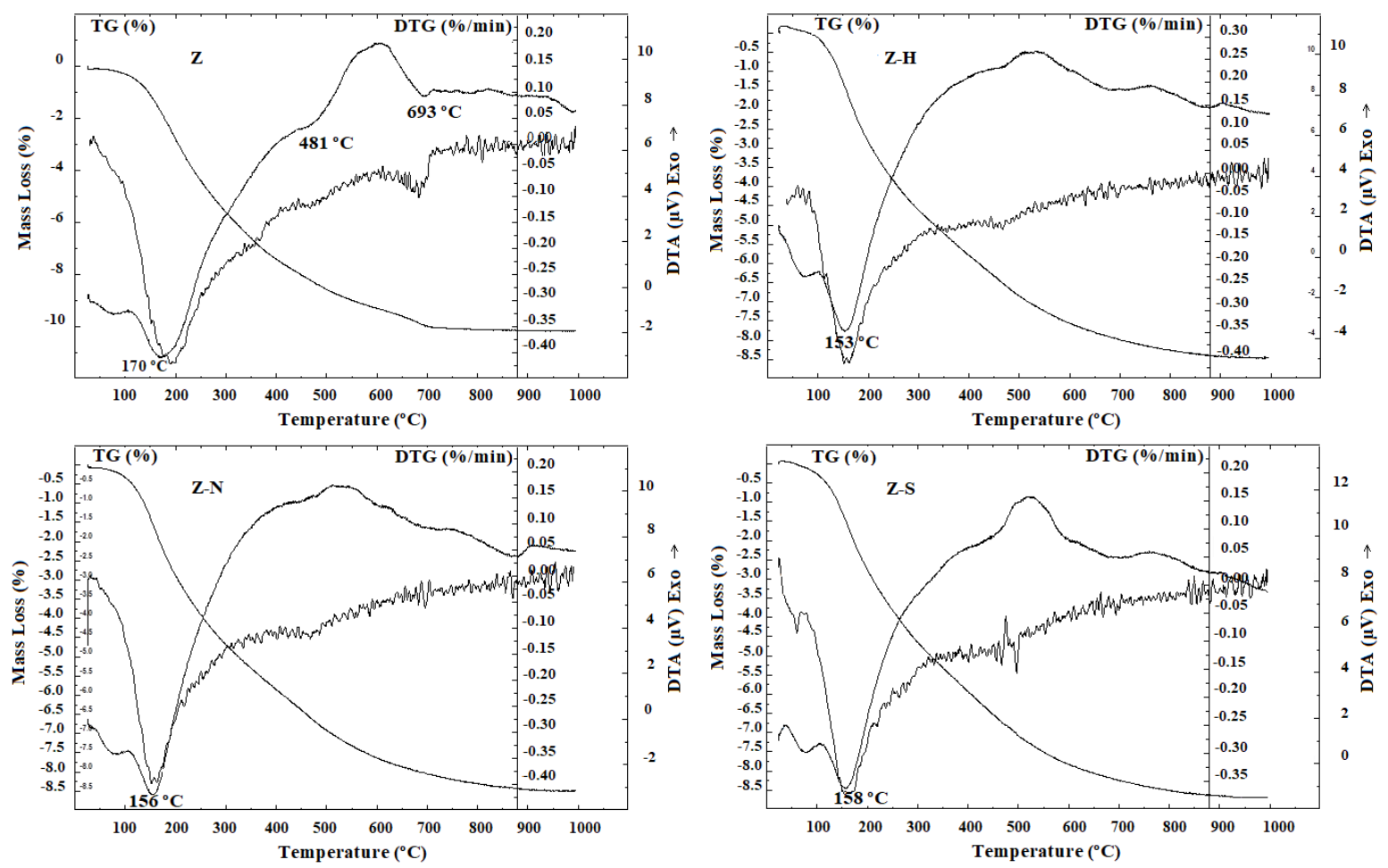

Figure 2. TG-DTG-DTA curves of natural and acid treated zeolite samples

Table 2. Mass loss (\%) of the natural and acid treated zeolites used at different temperature ranges

\begin{tabular}{|c|c|c|c|c|c|c|c|c|c|}
\hline Sample & $\begin{array}{l}30- \\
100^{\circ} \mathrm{C}\end{array}$ & $\begin{array}{l}100- \\
200^{\circ} \mathrm{C}\end{array}$ & $\begin{array}{l}200- \\
300^{\circ} \mathrm{C}\end{array}$ & $\begin{array}{l}300- \\
400{ }^{\circ} \mathrm{C}\end{array}$ & $\begin{array}{l}400- \\
500^{\circ} \mathrm{C}\end{array}$ & $\begin{array}{l}500- \\
600^{\circ} \mathrm{C}\end{array}$ & $\begin{array}{l}600- \\
700^{\circ} \mathrm{C}\end{array}$ & $\begin{array}{l}700- \\
1000^{\circ} \mathrm{C}\end{array}$ & $\begin{array}{l}\text { Total Mass } \\
\text { Loss (\%) }\end{array}$ \\
\hline $\mathrm{Z}$ & 0.31 & 2.52 & 2.79 & 1.80 & 1.16 & 0.73 & 0.68 & 0.15 & 10.14 \\
\hline Z-H & 0.12 & 2.73 & 1.77 & 1.18 & 1.06 & 0.69 & 0.44 & 0.45 & 8.44 \\
\hline Z-N & 0.34 & 2.56 & 1.79 & 1.17 & 1.06 & 0.71 & 0.43 & 0.40 & 8.46 \\
\hline Z-S & 0.24 & 2.49 & 1.85 & 1.26 & 1.15 & 0.71 & 0.43 & 0.38 & 8.51 \\
\hline
\end{tabular}




\section{CONCLUSIONS}

- It was determined that the acid treatment caused the significant changes in chemical composition of zeolite depending on the types of acid solutions.

- The XRD pattern of the zeolite sample indicated that it contained mordenite and clinoptilolite as the major zeolite minerals with smaller amounts of quartz, feldspar and clay mineral. After treatments with hydrochloric, sulphuric and nitric acid solutions, the most characteristic clinoptilolite peaks of the zeolite samples substantially decreased, but the intensity of the diffraction peaks corresponding to quartz increased considerably. This could be attributed to partial dealumination and partial removal of exchangeable cations of the structure.

- All acid-treated zeolite samples showed a similar thermal behavior to natural zeolite. DTA curves of acid-treated zeolite samples exhibited thermal stability up to high temperatures. The acidtreated samples showed a single endothermic peak at temperature ranging between 153 and 158 ${ }^{\circ} \mathrm{C}$ as a result of a single-step dehydration process. In addition, in the TG curves of acid-treated zeolite samples, the total mass losses were lower than that of the natural zeolite sample. Partial dealumination lead to increase in the hydrophobic nature of the zeolite.

- The fact that natural zeolites are low-cost and abundant resources makes these materials very attractive for many fields of application. Consequently, the determination of thermal and structural properties of natural and modified zeolites has great importance.

\section{REFERENCES}

[1] Breck DW. Zeolite Molecular Sieves. New York, NY, USA: John Wiley and Sons, 1974.

[2] Gottardi G, Galli E. Natural Zeolites, Berlin: Springer-Verlag, 1985.

[3] Yang RT. Adsorbents. New York: Wiley, 2003.

[4] Meier WM. The crystal structure of mordenite (ptilolite), Z. Kristallogr. 1961, 115, 439-450.

[5] Baerlocher CH, Meier WM, Olson DH. Atlas of Zeolite Framework Types. 5th ed., Amsterdam, the Netherlands: Elsevier, 2001.

[6] Misaelides P, Godelitsas A, Link F, Baumann H. Application of the 27Al(p, $\gamma$ ) 28Si nuclear reaction to the characterization of the near-surface layers of acid-treated HEU-type zeolite crystals. Microporous Mesoporous Mater 1996; 6: 37-42.

[7] Hernandez MA, Petranovskii V, Avalos M, Portillo R, Rojas F, Lara VH. Influence of the Si/Al framework ratio on the microporosity of dealuminated mordenite as determined from $\mathrm{N}_{2}$ adsorption. Sep Sci Technol 2006; 41(9); 1907-1925.

[8] Korkuna O, Leboda R, Skubiszewska-Zeiba J, Vrublevska T, Gunko VM, Ryczkowski J. Structural and physicochemical properties of natural zeolites: clinoptilolite and mordenite. Microporous Mesoporous Mater 2006; 87: 243-254 
[9] Elaiopoulos K, Perraki Th, Grigoropoulou E. Mineralogical study and porosimetry measurements of zeolites from Scaloma area, Thrace, Greece. Microporous Mesoporous Mater 2008; 112: 441 449.

[10] Elaiopoulos K, Perraki Th, Grigoropoulou E. Monitoring the effect of hydrothermal treatments on the structure of a natural zeolite through a combined XRD, FTIR, SEM and $\mathrm{N}_{2}$-porosimetry analysis. Microporous Mesoporous Mater 2010; 134: 29-43.

[11] Garcia-Basabe Y, Rodriguez-Iznaga I, de Menorval L, Llewellyn P, Maurin G, Lewisf DW, Binionsf R, Autieg MA, Ruiz-Salvadora R. Step-wise dealumination of natural clinoptilolite: structural and physicochemical characterization. Microporous Mesoporous Mater 2010; 135(1-3): $187-196$.

[12] Ates A, Hardacre C. The effect of various treatment conditions on natural zeolites: Ion exchange, acidic, thermal and steam treatments, J Colloid Interf Sci 2012; 372: 130-140.

[13] Mansouri N, Rikhtegar N, Panahi HA, Atabi F, Shahraki BK. Porosity, characterization and structural properties of natural zeolite - clinoptilolite - as a sorbent. Environment Protection Engineering 2013; 39: 139-152.

[14] Xu W, Li LY, Grace JR. Dealumination of clinoptilolite and its effect on zinc removal from acid rock drainage. Chemosphere 2014; 111: 427-433.

[15] Lisa EB, Maria GJ. The effect of acid treatment on the reactivity of natural zeolites used as supplementary cementitious materials. Cement Concrete Res 2016; 79: 185-193.

[16] Wang C, Cao L, Huang J. Influences of acid and heat treatments on the structure and water vapor adsorption property of natural zeolite. Surf Interface Anal 2017; 49: 1249-1255.

[17] Ateş A. Effect of alkali-treatment on the characteristics of natural zeolites with different compositions. J Colloid Interface Sci 2018; 523: 266-281.

[18] Abatal M, Córdova Quiroz Atl V, Olguín MT, Vázquez-Olmos AR, Vargas J, Anguebes-Franseschi F, Giácoman-Vallejos G. Sorption of $\mathrm{Pb}$ (II) from aqueous solutions by Acid-Modified Clinoptilolite-Rich Tuffs with Different Si/Al Ratios. Appl Sci 2019; 9: 2415.

[19] Stocker K, Ellersdorfer M, Lechleitner A, Lubensky, J.; Raith JR. Impact of concentrated acid, base and salt pretreatments on the characteristics of natural clinoptilolite and its ammonium uptake from model solution and real effluents. Microporous Mesoporous Mat. 2019; 288: 109553.

[20] Wang C, Leng S, Guo H, Cao L, Huang J. Acid and alkali treatments for regulation of hydrophilicity/hydrophobicity of natural zeolite. Appl Surf Sci 2019; 478: 319-326.

[21] Esenli F. Natural zeolite reserves, mining, production, and market situation. In: National Zeolite Symposium; 2 July 2002; Tubitak-MAM, Gebze, Kocaeli (in Turkish).

[22] Barrer RM, Makki MB. Molecular Sieve Sorbents from Clinoptilolite. Canadian J Chem 1964; (42): 1481-1487.

[23] Moore DM, Reynolds Jr RC. X-ray Diffraction and the Identification and Analysis of Clay Minerals, 2nd edn., New York: Oxford University Press, 1997. 